\title{
The Ability of Creative Mathematical Thinking of Madrasah's Students
}

\author{
Maifalinda Fatra, Tita Khalis Maryati \\ Syarif Hidayatullah State Islamic University Jakarta, Jl. Ir. H. Djuanda 95, Ciputat, Indonesia \\ Corresponding e-mail: maifalinda.fatra@uinjkt.ac.id
}

\begin{abstract}
Educated people have the power of thought, reason and intelligence which support them to overcome the problems they face in everyday live. One way to develop these powers is to develop a creative thinking on mathematics. This study investigated the effect of the implementation of Curriculum 13 (K13) on madrasahs students' creative mathematical thinking. This study employed descriptive quantitative approach. Participants included 107 students from 5 public madrasah aliyah (Islamic senior high school and 173 students from 5 public madrasah tsanawiyah (Islamic junior high school) in the province of Jakarta. Data were gathered using creative mathematical thinking assessments. 5 items on the test measured students' creative thinking (self-efficacy, fluency, flexibility, originality and elaboration skills). The results showed that the madrasah students' creative mathematical thinking was very low with the average score of 23.14 for madrasah Aliyah students and 15.69 for Madrasah Tsanawiyah students.
\end{abstract}

Keywords: creative mathematical thinking, curriculum 2013

\section{INTRODUCTION}

Someone who has the ability to think creatively will have the ability to solve problems that exist in his daily life. It can be said that a person with creative thinking ability will be an effective person in learning, society, work, and life. Creative thinking skills are the ability to find many possible answers to a problem, where the emphasis is on quantity, usability, and diversity of answers. The more numerous and varied possible answers the more creative one is, but the diversity of those answers is the right and appropriate answer to the problem. By thinking creatively one can manifest itself through various creations of his creation, whether in the form of ideas, ideas, or products.

The ability to think creatively can not come by itself. This ability should be trained and familiarized in a person as early as possible. Educators should support their pupils to dvelop this skills by teaching them how to think creatively through learning in the classroom. Creative thinking skills are very important for learners, because by thinking creatively, learners can convey their ideas openly. A person who has the ability to think creatively will have the ability to solve problems that exist in the learning or in daily life both routine and non routine problems in various ways.

Mathematics lesson which designed to develop creative thinking ability, in line with the purpose of learning mathematics are: (1). train thinking and reasoning in drawing conclusions, for example through investigation, exploration, experimentation, showing similarities, differences, consistency and inconsistencies; (2). Developing creative activities that involve imagination, intuition, and discovery by developing divergent, original thinking, curiosity, making predictions and guesswork, and experimenting; (3) Develop problem solving skills; (4). Developing the ability to convey information or communicate ideas among others through oral conversations, charts, maps, diagrams, in explaining ideas (Ekawati, P4TK Matematika, 2011). In mathematics lessons learners are taught how to solve problems in various ways and strategies, it aims to train their categorical thinking. Learning and Teaching Scotland (LTS, 2004) states that when creative thinking develops in a person, it produces many ideas, makes connections, has many 
perspectives on things, makes and does imagination, and cares about results.

If the problems mentioned above are associated with core competencies (kompetensi inti /KI) formulas, it becomes interesting to examine "how is the impact of this K13 implementation on learning mathematics in improving students' mathematical creative thinking ability?" So that the study focused on the following problems (1). How is the ability of creative mathematical thinking of Madrasah Tsanawiyah students in DKI Jakarta ?; (2). How is the ability of creative mathematical thinking of Madrasah Aliyah Negeri students in DKI Jakarta?

Johnson in Siswono (2004) suggests that creative thinking that implies perseverance, personal discipline and attention involves mental activities such as raising problems, considering new rules and unusual ideas with an open mind, making connections, especially between something in common, linking one another freely, carrying out imaginations in every situation that evokes new and different ideas, and cares about intuition. Furthermore Coleman and Hammen in Sukmadinata (2004) explained that creative thinking is a mental activity to improve the originality, and the sharpness of understanding (insight) in developing something (generating). In addition, Sumarmo (2010) argued that there are five core creative thinking, among others:

a) Self-efficacy is the ability and independence in self-control; dare to face problems; optimistic, confident, problem as challenge and opportunity.

b) Flexibility (empathy) is to empathize, appreciate, accept different opinions, be open, steady / tolerant of uncertainty, have a sense of humor.

c) Proficiency / expertise is working in a precise, thorough, precise, and thorough, have a clear vision and purpose, always doing testing on the activities undertaken.

d) Awareness is doing the activity consciously, thinking metacognisi, giving rational reasons for the activities it does.

e) Dependence of giving and receiving, showing interconnectedness, conflict as something useful.

Based on the expert opinion that has been stated above and other studies (for eaxmple Paul (1994): Trefingger (2003), Pepkin (2000); Myrmel (2003): Nilson (2014), the researcher concludes that the ability of creative thinking is the ability of a person to create and solve problems in different ways to produce conclusions and new products are characterized by fluency, flexibility, oroginality and elaboratioon.

a) The skill of fluent thinking (fluency)

The ability to think smoothly can be defined as a skill in triggering many ideas, answers, problem solving or questions, providing many ways or suggestions for doing things, and always thinking of more than one answer.

b) Flexibility skills (flexibility)

A person with a flexible thinking skill will be able to produce varied answers, ideas, or questions, be able to see a problem from different perspectives, search for different alternatives or directions, and be able to change the way of thinking or approach.

c) Original thinking skills (originality)

Original thinking ability is the ability to create new and unique expressions, think of unconventional ways of expressing oneself, and the ability to make unusual combinations of parts or elements.

d) Elaboration skills (elaboration)

Detailed skill is the ability to enrich and develop an idea or product, and add or detail details of an object, idea or situation so that it becomes more interesting.

\section{METHODS}

This research was conducted in State Madrasah Aliyah (MAN) and State Madrasah Tsanawiyah (MTsN) in DKI Jakarta. The method used is descriptive method in which the researcher tries to describe the problem or phenomenon that happened in State Madrasah Tsanawiyah (MTsN) and State Madrasah Aliyah (MAN) in DKI Jakarta related to the impact of curriculum implementation 2013 in improving students' mathematical creative thinking ability. The sample of this research is State Madrasah Tsanawiyah (MTsN) and Madrasah Aliyah Negeri (MAN) of DKI Jakarta which have implemented Curriculum 2013, each consisting of 5 Madrasahs. Sampling technique used in random sampling area. From each State Madrasah Tsanawiyah (MTsN) was selected 1 class 9 of the parallel class that existed at random. For Madrasah Aliyah Negeri (MAN) selected 1 class 11 randomly from existing parallel class.

Data was generated in the form of test of mathematical creative thinking ability consisting of 5 item. The instrument validation process is performed by content analysis techniques through 
expert review. Besides, the researcher also uses interview sheet and observation sheet. Data analysis techniques used descriptive analysis, with data presentation in the form of tables, graphs and diagrams and percentages. It aims to get an overview of the mathematical cretative thinking ability of Madrasah Aliyah Negeri and Madrasah Tsanawiyah Negeri (MTsN) students in DKI Jakarta.

\section{RESULTS AND DISCUSSION}

The data used is the test results of students' mathematical creative thinking ability. The test is a matter of mathematical creative thinking ability which is arranged in the form of a description problem consisting of 5 items. After all the research subjects completed the test, then the data collected in though and presented in the form of tables and graphs. The following will be presented data test results of students' creative thinking skills mathematically.

a) Ability of Mathematically Creative Thinking of Madrasah Aliyah Students

Data were obtained from 107 students from 5 MANs in Jakarta who have applied K13 in their learning. From the data obtained there is 1 student who has the lowest value of 9.78 and 1 person the highest value of 40.2 from the scale of the value used $1-100$. Based on data processing descriptively obtained an average value of 23.14, median 21, 26 and mode 18.79 and variance 61.54 and standard deviation of 7.84. The ability of students' mathematical creative thinking that learners apply K13 is still very low. In general, students' mathematical creative thinking ability in terms of the average value obtained, is still far from expectations. When viewed from the aspects studied ie smoothness, novelty, rings and flexibility. The average value of ability from every aspect of creative thinking is only close to $10 \%$ (for a scale of 1-100). In more detail consider the following graph.

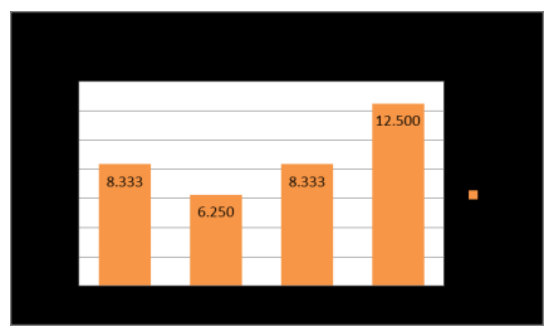

Figure.1 Ability of Mathematically Creative Thinking of Madrasah Aliyah Students

b) Ability of Mathematical Creative Thinking of Madrasah Tsanawiyah Students
Data obtained from 173 MTsN Jakarta students who have applied K13 in mathematics learning, obtained the lowest value 1.25 and the highest score 50 . Students who get the lowest value of $12.14 \%$ and the highest value of $0.58 \%$. From the descriptive analysis, it is known that MTsN students' mathematical creative thinking ability with average value is 15,69 , median, 15,56 , mode 16,50 , and variance 69,33 and standard deviation equal to 8,33 . This data shows the creative thinking ability of students mathematics is still very low. This is no different from students' mathematical creativity. If it is seen the ability to think the mathematical cretive students MTsN somewhat different between aspects. In the aspect of the smoothness of the percentage relative better than 2 other aspects of flexibility and kebarua. More clearly note the following graph.

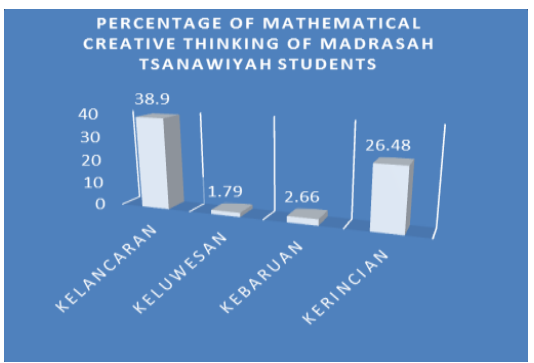

Figure 2. Ability of Mathematical Creative Thinking of Madrasah Tsanawiyah Students

c) Comparison of Mathematical Creative Thinking Skills of MAN and MTsN Students

1) Fluency Aspect

The ability to think creatively the aspect of fluency is the ability to build many ideas, the more ideas obtained the better the alternative solution to the problem. From the test given, the data obtained students' ability on the indicator of fluency for students Aliyah of $8.33 \%$ and Students Tsanawiyah for $38.9 \%$.

2) Flexibility Aspect

The ability to think creatively aspects of flexibility has many functions in solving problems given, because flexibility to build diverse ideas to make students dare to try various approaches or ways to solve problems given. From the student's answer in solving the problem, the students' ability ability of the flexibility aspect for the students of Aliyah is $12,5 \%$ and the student of Tsanawiyah is $1,79 \%$. Students only solve the problem according to the algorithm that is exemplified. The aspect of flexibility in MTsN students is so low they 
have not been able to construct diverse ideas to solve the problem given only to be tied to the examples taught by the teacher.

3) Detailed Aspects (Elaboration)

The ability to think creatively in terms of detail or so-called elaboration is the ability to decipher the answers so that they can solve a given problem or problem. However, on the test given, the result of elaboration aspect for Aliyah students is $8.3 \%$ and Students Tsanawiyah is $26.48 \%$. The student's ability in this aspect is better than the flexibility indicator. In this aspect MTsN students began to be able to decipher the answers they were doing even though only a few students. Unlike the MAN students, they are still not able to decipher the answers well but new. able to describe in detail the problems in the matter.

4) Novelty Aspect

The ability to think creatively on the indicator of novelty or originality is the most difficult stage among other stages because students are required to answer questions in an unusual and unique way. Creative thinking ability in novelty aspect for MAN students is $6.25 \%$ and MTsN students only reached $2.66 \%$, this aspect is slightly better than aspect of flexibility. Students MAN and MtsN still not able to answer questions in a variety of ways, they are still fixated by the answers dicotohkan by teachers.

The students' creative thinking ability as described above is still far from expectations. The students' average mathematical creative thinking ability is still very low. This is allegedly because students are not familiar with creative thinking questions because they are still very little in textbooks and teachers still rarely give high-level thinking problems. This data reinforces the results of TIMMS and PISA which shows the high thinking ability of Indonesian students is still relatively low and get the lowest position of the entire participating countries.

In learning K13 students are required to be able to build the concept independently, while the teacher only as a facilitator. Besides, the learning that is usually done by teachers so far has not trained students to learn independently. The teacher explains the concepts in detail and the students are not directed and required to find the concept in depth. Students are only asked actively to do the exercises only. Based on the theory of constructivism learning that is now used as the foundation of learning in school students should be able to build the concept independently through the process of cooperation in group learning so that formed learning community.

\section{CONCLUSIONS}

The environmental education curriculum as local curriculum in South Tangerang district is designed with referring to Tbilisi declaration (1977). With the five categories of environmental education objectives, namely awareness, knowledge, attitudes, skills, and participation, the lesson would not only deal with cognitive aspect of thinking, but also about action. The coverage context recommended by national curriculum which includes local, national, and regional context would drive the lesson in to a broader point of views.

\section{ACKNOWLEDGEMENTS}

This paper is a part of preliminary project between Tangerang Selatan District office of MOEC, JICA, and IEPF. Special thanks to Dr. Yanti Herlanti who has been encouraging in developing this project as well as involving various academic colleagues.

\section{REFERENCES}

Paul, E. (1994), Constructing Mathematical Knowledge:Epistemology and Mathematic Education. USA: The Falmer Press.

Ekawati, E. (2011). Peran, Fungsi, Tujuan, dan Karakteristik Matematika Sekolah. dalam http://p4tkmatematika.org

Myrmel, M. K. (2003). Effects of Using Creative Problem Solving in English Grade Technology Education Class at Hopkins North Junior High School.Thesis, The Graduate school, University of WisconsinStout.

Nilson, C. (2014). Developing Children's Critical Thinking through Creative Arts Exposure, The International Journal of Art Education, Champaign, Ilinois, USA.

Pepkin, K. L. (2000). Creative Problem Solving in Math. Citing Internet sources URL http://m2sconf.uh.edu/honors/honors-and-the-schools/houstonteachers-institute/curriculum-units/pdfs/2000/ articulating-the-creative-experience/pepkin-00creativity.pdf

Trefingger, D. J., Isaksen, S. G., Dorval, K. B. (2003). Creative Problem Solving (CPS Version 6.1 ${ }^{T M}$ ) A Contemporary Framework for Managing Change. Citing Internet sources URL: 
http://www.creativelearning.com/PDF/CPSVersion6 1.pdf

Sumarmo, U. (2010). Berpikir dan Disposisi Matematik:Apa,Mengapa, dan Bagaimana Dikembangkan Pada Peserta Didik. Bandung: FPMIPA UPI.

Sukmadinata, N.S. (2004). Kurikulum dan Pembelajaran Kompetensi. Bandung: Yayasan Kesuma Karya. 